\title{
INTERAKSI SISWA DALAM PEMBELAJARAN MATEMATIKA DI KELAS XII SMK NEGERI 7 SAMARINDA
}

\author{
Laili Faidatul Mardiah ${ }^{1)}$ \\ Kukuh ${ }^{2)}$ \\ Usfandi Haryaka ${ }^{3)}$ \\ 1), 2), 3) Program Studi Pendidikan Matematika, Universitas Mulawarman \\ Email: ${ }^{1)}$ mardiahlailifaidatul@gmail.com
}

\begin{abstract}
ABSTRAK
Kegiatan belajar mengajar di sekolah tidak lepas dari interaksi siswa dengan guru. Penelitian deskriptif kualitatif ini bertujuan untuk mendeskripsikan interaksi yang terjadi antara siswa dengan guru dan faktor-faktor terjadinya interaksi siswa dengan guru dalam proses pembelajaran matematika. Subjek penelitian ini adalah siswa kelas XII TKJ-1 SMK Negeri 7 Samarinda, dengan objek yaitu interaksi siswa dan guru dan faktor yang mendasari terjadinya interaksi. Teknik pengumpulan data yang digunakan meliputi observasi, dokumentasi, dan wawancara. Teknik analisis data meliputi reduksi data, penyajian data, penarikan kesimpulan, dan pemeriksaan keabsahan data. Berdasarkan hasil penelitian, interaksi dalam pembelajaran meliputi motivasi guru kepada siswa, perintah guru kepada siswa untuk membaca contoh permasalahan, penjelasan guru kepada siswa, pemberian soal latihan, tanya jawab antara guru dengan siswa, dan kegiatan diskusi kelompok. Berdasarkan hasil wawancara, faktor terjadinya interaksi adalah upaya guru memaksimalkan penggunaan sarana-sarana yang dapat menunjang terjalinnya interaksi, minat siswa terhadap pelajaran matematika, inteligensi siswa, anggapan mata pelajaran jurusan lebih penting, kondisi kelas yang kurang mendukung untuk jumlah siswa dalam kelas, dan pemanfaatan sumber-sumber pelajaran dari siswa. Interaksi yang terjadi tercakup dalam interaksi satu arah, interaksi dua arah dan interaksi banyak arah. Ketiga interaksi ini disebabkan oleh faktor guru dan siswa, faktor bahan atau materi pengajaran, dan faktor situasi.
\end{abstract}

Kata kunci: Deskriptif kualitatif, Interaksi siswa, Pembelajaran matematika.

\begin{abstract}
Teaching and learning activities in schools cannot be separated from the interaction between students and teachers. This qualitative descriptive study aimed to describe interactions that occur between students and teachers, and factors of student-teacher interaction in the mathematics learning process. Subjects of this study were students of class XII TKJ-1 SMK Negeri 7 Samarinda. Objects of this research were the studentteacher interaction and the interaction factor. Data collection techniques used include observation, documentation, and interviews. Data analysis techniques include data reduction, data presentation, drawing conclusions, and data validity checking. Based on
\end{abstract}


research results, interactions in learning included teacher motivation to students, teacher orders to read examples of problems, teacher explanations to students, giving practice questions, question and answer between teacher and students, and group discussion activities. Based on the interview, factor of the interaction were teacher's efforts to maximize facilities that can support the interaction, student interest in mathematics, student intelligence, opinion that majoring subjects are more important, class conditions unfavorable to the number of students in classroom, utilization of learning resources from students. The interactions included one-way interactions, two-way interactions and multi-way interactions. These are caused by teacher-student factors, material factors or teaching materials, and situation factors.

Keywords: Qualitative descriptive, Student interaction, Mathematics learning

\section{PENDAHULUAN}

Salah satu kegiatan hidup manusia yang tidak terlepas dari proses interaksi atau komunikasi adalah kegiatan belajar mengajar di sekolah. Sekolah merupakan lembaga pendidikan formal yang diharapkan mampu menjadi ujung tombak kemajuan sebuah bangsa. Bangsa akan menjadi maju apabila memiliki sumber daya manusia yang berkualitas atau bermutu tinggi. Adapun mutu bangsa dikemudian hari tergantung pada pendidikan yang diterima oleh generasi masa kini, terutama melalui pendidikan formal yang diterima di sekolah.

Perbaikan kurikulum merupakan salah satu upaya dalam memperbaiki pendidikan. Pemberlakuan Kurikulum 2013 (K-13) menuntut sejumlah perubahan mendasar pada proses pembelajaran yang berlangsung di sekolah. Proses pembelajaran pada K-13 mengamanatkan esensi pendekatan ilmiah atau pendekatan saintifik. Menurut Permendikbud Nomor 81 A Tahun 2013 pada Lampiran IV tentang Pedoman Umum Pembelajaran dinyatakan bahwa proses pembelajaran terdiri atas lima pengamalaman belajar pokok, yaitu: mengamati, menanya, mengumpulkan informasi, menalar, dan mengkomunikasikan.

Cockroft mengemukakan bahwa matematika perlu diajarkan karena sangat dibutuhkan dan berguna dalam kehidupan sehari-hari, bagi sains, perdagangan dan industri. Matematika menyediakan suatu daya, alat komunikasi yang singkat dan ambigius serta berfungsi sebagai alat untuk mendeskripsikan dan memprediksi. Matematika mencapai kekuatannya melalui simbol-simbolnya, tata bahasa dan kaidah bahasa (syntax) pada dirinya, serta mengembangkan pola berpikir kritis, aksiomatik, logis, dan deduktif (Uno, 2012:128).

Sardiman (2014:2) menyatakan bahwa interaksi belajar-mengajar mengandung suatu arti adanya kegiatan interaksi dari tenaga pengajar yang melaksanakan tugas mengajar di satu pihak, dengan warga belajar (siswa, anak didik/ subjek belajar) yang sedang melaksanakan kegiatan belajar di pihak lain.

Sudjana (dalam Permatasari, 2011:8) menyatakan interaksi belajar mengajar dapat dilihat dalam empat hal yaitu tanya jawab atau dialog antara guru dengan siswa atau antara siswa dengan 
siswa, bantuan guru terhadap siswa yang mengalami kesulitan belajar, baik secara individu maupun kelompok, teguran guru, dan peran guru sebagai fasilitator. Sedangkan Sadirman (dalam Dimyanti dan Mudjiono, 2013:120) menyatakan bentuk-bentuk interaksi, berupa penjelasan, diskusi, pertanyaan, refleksi atau persetujuan yang digunakan untuk mencapai dalam penyelesaian masalah.

\section{METODE PENELITIAN}

Penelitian ini menggunakan metode kualitatif. Subjek dalam penelitian ini adalah siswa kelas XII TKJ-1 SMK Negeri 7 Samarinda, sedangkan objek penelitian ini adalah interaksi siswa dan guru dan faktor yang mendasari terjadinya interaksi pada materi matriks, bunga, pertumbuhan dan peluruhan. Penelitian ini dilaksanakan pada bulan Agustus hingga Oktober semester ganjil tahun ajaran 2015/2016.

Teknik pengumpulan data yang digunakan meliputi observasi, dokumentasi, dan wawancara. Teknik analisis data dalam penelitian ini meliputi reduksi data, penyajian data, penarikan kesimpulan, dan pemeriksaan keabsahan data (triangulasi). Observasi dilakukan sebanyak 10 kali dengan dokumentasi berupa catatan siswa dan beberapa aktifitas siswa dan guru selama proses pembelajaran, yaitu ketika guru memberikan penjelasan, ketika siswa maju ke depan mengerjakan soal latihan dan kegiatan lainnya. Wawancara dilakukan dengan 9 orang siswa, sebagai wakil dari siswa yang terlihat aktif dan tidak aktif selama proses pembelajaran yang memberikan pengaruh terhadap terwujudnya interaksi siswa dan guru selama proses pembelajaran.

Data yang diambil berupa data kualitatif yaitu catatan terkait interaksi yang terjadi selama proses pembelajaran berlangsung. Kemudian dari catatan lapangan tersebut diidentifikasi bentukbentuk interaksi yang terjadi antara siswa dengan guru selama proses pembelajaran dan mengidentifikasi pula siswa yang terlihat aktif berinteraksi dan siswa yang kurang berinteraksi selama pembelajaran berlangsung sehingga kemudian dapat dikategorikan bentuk-bentuk interaksi yang terjadi selama pembelajaran.

\section{HASIL PENELITIAN DAN PEMBA- HASAN}

Pelaksanaan proses pembelajaran matematika dimulai dengan persiapan dan kegiatan awal pembelajaran. Guru membuka kegiatan pembelajaran dengan mengucap salam, menanyakan kesiapan siswa untuk mengikuti kegiatan belajar mengajar dan selanjutnya pada beberapa pertemuan guru memberikan nasihatnasihat atau motivasi belajar kepada siswa. Setelah kegiatan pengkondisian kelas untuk mengikuti kegiatan belajar mengajar, berikutnya adalah kegiatan apersepsi. Kegiatan apersepsi tidak selalu dilakukan oleh guru, yaitu hanya 3 pertemuan dari 10 pertemuan observasi. Selain 3 pertemuan tersebut, setelah mengkondisikan siswa untuk mengikuti kegiatan belajar mengajar, guru menyampaikan materi yang akan menjadi pokok bahasan.

Pada kegiatan inti pelajaran, guru memulai pembahasan materi inti dengan mengarahkan siswa untuk membaca penjelasan terkait contoh-contoh 
penyelesaian pada buku ajar siswa. Guru juga memberikan contoh-contoh lain yang dibuat oleh guru sehingga lebih memudahkan siswa dalam memahami materi yang menjadi pokok bahasan, dan dilanjutkan dengan pemberian soal latihan.

Hasil observasi menunjukkan bahwa pada pertemuan ke-7 dan pertemuan ke-10, guru menggunakan metode diskusi untuk membantu siswa memahami materi yang sedang menjadi topik bahasan. Pada saat kegiatan diskusi, guru berkeliling mengecek kegiatan diskusi yang dilakukan siswa. Guru memberikan bimbingan kepada siswa secara individu maupun kelompok ketika ada siswa bertanya. Setelah guru melihat masing-masing kelompok sudah ada yang menemukan jawaban dari permasalahan yang diberikan, dan waktu untuk diskusi sudah cukup, guru meminta perwakilan dari setiap kelompok untuk maju ke depan mempresentasikan penyelesaian masalah yang diperoleh.

Pada kegiatan akhir pembelajaran, guru menyampaikan materi yang akan dipelajari untuk pertemuan selanjutnya. Untuk beberapa pertemuan, guru juga memberikan tugas kepada siswa.

Pada penelitian ini, faktor-faktor yang mendasari terjadinya interaksi siswa dan guru selama proses pembelajaran dapat diketahui dari hasil observasi dan hasil wawancara. Wawancara dilakukan setelah selesai waktu pembelajaran matematika kepada 9 orang siswa. Adapun hasil penelitian yang menunjukkan faktor-faktor yang mendasari terjadinya interaksi siswa dan guru pada pembelajaran matematika di kelas XII TKJ-1 SMK Negeri 7 Samarinda adalah sebagai berikut.

1) Faktor Bahan atau Materi Pengajaran Hasil wawancara pada siswa yang terkait dengan bahan atau materi pengajaran yang menjadi faktor terjadinya interaksi siswa dan guru selama proses pembelajaran. Hasil wawancara dengan guru juga menunjukkan bahwa materi yang menarik menjadi faktor terjalinnya interaksi guru dan siswa dalam proses pembelajaran.

2) Faktor Guru dan Siswa

Melalui 10 pertemuan hasil kegiatan observasi, dapat diketahui bahwa secara umum aktivitas-aktivitas yang dilakukan guru pada saat proses pembelajaran adalah sebagai berikut.

a. Guru menyampaikan materi yang akan menjadi sub pokok bahasan.

b. Guru melakukan kegiatan apersepsi dan terkadang membahas pekerjaan rumah pada pertemuan sebelumnya.

c. Guru meminta siswa untuk membaca buku ajar yang terkait dengan materi yang akan menjadi sub pokok bahasan.

d. Guru membahas sub pokok bahasan yang telah dibaca siswa.

e. Guru memberikan penjelasan terkait contoh masalah sesuai sub pokok bahasan

f. Guru memberikan soal latihan

g. Guru membimbing siswa menyimpulkan materi yang menjadi sub pokok bahasan

h. Guru menyampaikan sub pokok bahasan yang akan dipelajari pada pertemuan berikutnya dan terkadang guru memberikan tugas.

Siswa jarang mengulang pelajaran matematika di rumah karena lebih fokus pada mata pelajaran jurusan. Dari 9 siswa yang diwawancarai, 5 siswa menjawab 
mengulang mata pelajaran matematika hanya ketika ada PR saja, 2 siswa menjawab jarang mengulang (pelajaran matematika) dan 2 orang menjawab mengulang (pelajaran matematika). Diantara alasan siswa yang hanya mengulang mata pelajaran matematika ketika ada PR saja.

3) Faktor Metode

Ketika proses pembelajaran di kelas, guru memadukan beberapa metode, diantaranya metode tanya jawab, metode ceramah, dan metode diskusi.

4) Faktor Sumber Pelajaran

Selama kegiatan belajar mengajar pelajaran matematika, guru dan siswa menjadikan buku paket sebagai sumber pelajaran. Pada setiap pertemuan, kegiatan pembahasan sub pokok bahasan diawali dengan membaca berbagai contoh permasalahan yang terdapat dalam buku paket.

5) Faktor Situasi

Berdasarkan hasil wawancara, beberapa siswa mengeluhkan jam pelajaran matematika yang diletakkan pada siang hari. Ruang kelas menjadi panas ketika siang hari, karena Air Conditioner (AC) kelas belum diservis sehingga masih menggunakan kipas angin. Kipas angin yang ada tidak mampu menjangkau setiap sudut ruangan dan ditambah kondisi kelas yang terlalu banyak siswa.

6) Faktor Alat dan Peralatan

Alat nonmaterial yang digunakan guru pada proses pembelajaran berupa nasihat, perintah dan arahan. Sedangkan alat material yang membantu guru selama proses pembelajaran berupa buku paket, papan tulis dan spidol.

7) Faktor Evaluasi
Pada setiap pertemuan, setelah memberikan penjelasan terkait sub pokok bahasan guru melakukan kegiatan evaluasi dengan memberikan soal latihan kepada siswa. Guru juga melakukan evaluasi terkait bab yang telah dibahas pada kegiatan belajar mengajar dengan melakukan kegiatan ulangan harian per bab.

Komponen guru merupakan komponen pembelajaran yang banyak memberikan pengaruh terhadap proses interaksi edukatif yang baik selama proses pembelajaran. Hasil observasi selama kegiatan pembelajaran di kelas XII TKJ-1 SMK Negeri 7 Samarinda menunjukkan bahwa guru mata pelajaran matematika mampu memberikan pengaruh yang positif terhadap proses interaksi edukatif yang baik. Guru memiliki kepribadian yang berwibawa, ketika guru memasuki kelas siswa yang awalnya ribut menjadi tenang dan mulai mengkondisikan diri untuk mengikuti kegiatan belajar mengajar. Cara guru berbicara atau berkomunikasi dengan siswa juga cukup baik, guru tidak gugup, tidak terlalu cepat, dan juga tidak terlalu lemah serta bahasa yang digunakan juga mudah untuk dipahami. Guru juga menguasai materi pelajaran yang disampaikan sehingga komunikasi antara guru dengan siswa ketika membahas materu berjalan dengan baik, guru memberikan penjelasan dengan lisan dan juga tulisan.

Komponen lain yang juga memberikan pengaruh terhadap proses interaksi pada proses pembelajaran adalah isi atau materi pembelajaran. Pada skripsi ini yang menjadi materi pembelajaran adalah materi bab matriks dan bab bunga, pertumbuhan dan peluruhan. Bab matriks 
merupakan bab yang sebelumnya sudah pernah dikenalkan di kelas $\mathrm{X}$, sehingga siswa memiliki gambaran terkait materi tersebut dan hal ini memberi kemudahan baik guru maupun siswa untuk mengkomunikasikannya. Sedangkan bab bunga, pertumbuhan dan peluruhan merupakan materi baru bagi siswa, namun materi ini terkait dengan barisan dan deret aritmatika serta barisan dan deret geometri yang sudah pernah dipelajari di kelas XI sehingga tidak begitu sulit bagi siswa mengikuti materi bab ini.

Komponen berikutnya yang juga memberikan pengaruh terhadap terwujudnya interaksi edukatif anatara siswa dan guru selama proses pembelajaran adalah siswa itu sendiri. Siswa yang mempunyai inteligensi tinggi cenderung aktif selama kegiatan belajar mengajar berlangsung. Maka harus ada kemauan atau motivasi dari dalam diri siswa itu sendiri untuk terus belajar. Dari hasil wawancara terhadap beberapa siswa, terdapat beberapa karakter siswa, ada siswa yang kurang dalam mengulang materi yang telah dipelajari dan sebaliknya ada siswa yang selalu menyempatkan mengulang materi yang telah dipelajari di rumah, ada siswa yang kurang berusaha atau cenderung malas mengerjakan tugas yang diberikan guru da nada siswa yang berupaya sunguhsungguh mencoba menyelesaikan tugas yang diberikan guru, jika siswa ini mengalami kesulitan maka ia akan mencari referensi dari buku selain buku ajar yang disediakan sekolah atau mencarinya diinternet. Saat kegiatan pembelajaran berlangsung, karakterkarakter siswa yang berbeda ini memberikan tampilan yang berbeda pula terkait dengan interaksinya selama mengikuti kegiatan belajar mengajar di kelas. Siswa yang mempunyai inteligensi tinggi atau pun siswa yang memiliki kemauan untuk mengulang materi pelajaran di rumah atau melakukan upayaupaya lainnya untuk menambah wawasnnya maka di kelas cenderung lebih aktif, mulai dari bertanya kepada guru, berdiskusi dengan temannya sampai pada membantu temannya memahami materi yang sedang dibahas di kelas. Maka hal ini menunjukkan bahwa komponen siswa dapat dikatakan juga mempunyai pengaruh terhadap interaksi edukatif siswa dan guru selama proses pembelajaran.

Suharsimi A (dalam Suryosubroto, 2009:43) mengatakan bahwa interaksi belajar mengajar meliputi menenangkan siswa, menyiapkan perlengkapan belajar, apersepsi (menghubungkan) dengan pelajaran yang lalu, membahas pekerjaan rumah, merumuskan tujuan pelajaran, guru mencatat atau mendiktekan, guru menerangkan secara lisan/ tulisan, guru mendemonstrasikan, siswa mencoba mendemontrasikan sendiri, siswa mencoba mendemonstrasikan secara kelompok, diskusi kelas, siswa belajar sendiri, guru memberi bantuan belajar secara individu kepada siswa, siswa bertanya, evaluasi formatif, guru menjelaskan kembali pelajaran tertentu, guru memberikan tugas.

Bentuk-bentuk interaksi belajar mengajar yang disebutkan oleh Suharsimi tersebut diantaranya nampak pada hasil penelitian. Hasil penelitian menunjukkan bahwa bentuk-bentuk interaksi siswa dan guru dalam pembelajaran matematika di $\begin{array}{lllll}\text { kelas } & \text { XII } & \text { TKJ-1 } & \text { SMK Negeri } 7\end{array}$ 
Samarinda Tahun Ajaran 2015/2016 terkhusus pada materi bab matriks dan bab bunga, pertumbuhan, dan peluruhan berupa nasihat atau motivasi guru kepada siswa, perintah guru kepada siswa, tanya jawab antara guru dengan siswa baik guru yang mengawali bertanya atau siswa yang bertanya, penjelasan guru kepada siswa, diskusi kelompok, pemberian soal latihan dan pemberian tugas dan penyampaian materi untuk pertemuan berikutnya pada akhir kegiatan pembelajaran.

Melalui hasil penelitian dapat diketahui bahwa bentuk interaksi yang termasuk dalam komunikasi satu arah adalah nasihat atau motivasi guru kepada siswa; perintah guru kepada siswa, lebih khususnya perintah untuk membaca buku ajar, perintah mendiskusikan suatu permasalahan, perintah mengerjakan soal latihan dan perintah mempresenrasikan hasil pekerjaan kelompok; tanya jawab antara guru dengan siswa yang sifatnya tidak memberikan balikan, baik guru yang mengawali bertanya atau siswa yang bertanya biasanya terjadi pada kegiatan apersepsi; penjelasan guru kepada siswa terkait sub pokok bahasan, pemberian soal latihan dan pemberian tugas dan penyampaian materi untuk pertemuan berikutnya pada akhir kegiatan pembelajaran.

Kemudian, bentuk interaksi yang termasuk dalam komunikasi dua arah adalah tanya jawab yang antara guru dengan siswa yang sifatnya saling memberikan balikan, contohnya ketika guru mengajak siswa mengamati contoh penyelesaian suatu permasalahan, kemudian guru memberikan kesempatan kepada siswa untuk bertanya atau memberikan tanggapan dan setelah itu guru kembali menanggapi atas tanggapan dari siswa. Sehingga dari aktivitas ini terjadi tanya jawab yang bersifat dua arah antara guru dengan siswa.

Sedangkan bentuk interaksi yang termasuk dalam banyak arah pada saat proses pembelajaran terjadi pada bentuk aktivitas diskusi. Guru membagi siswa menjadi beberapa kelompok, selanjutnya guru meminta siswa untuk mendiskusikan satu permasalahan pada setiap kelompok dan dilanjutkan dengan presentasi dari masing-masing kelompok, dan diakhir guru kembali menegaskan hasil presentasi kelompok dan membimbing siswa untuk membuat kesimpulan.

Hasil penelitian juga menunjukkan bahwa frekuensi terjadinya interaksi siswa dengan guru khususnya di kelas XII TKJ1 SMK Negeri 7 Samarinda ketika proses pembelajaran pada setiap pertemuan berbeda. Hal ini karena dipengaruhi beberapa faktor, baik factor internal yaitu dari dalam diri siswa dan juga faktor eksternal diantaranya guru, alokasi waktu, materi dan lain sebagainya.

Pada kegiatan pembelajaran bab matriks terjadinya interaksi guru dan siswa cenderung didominasi oleh guru. Guru mengawali kegiatan pembelajaran dengan tanya jawab. Selanjutnya guru meminta siswa membaca buku ajar siswa, kemudian guru mengarahkan siswa untuk memahami materi yang telah dibaca tersebut dengan kegiatan Tanya jawab. Guru juga memberikan penjelasan di papan tulis agar siswa lebih mudah memahami materi yang sedang dipelajari. Sedangkan pada kegiatan pembelajaran bab bunga, pertumbuhan dan peluruhan terjadinya interaksi guru dan siswa dapat dikatakan seimbang. Untuk pembahasan 
materi pada bab ini guru menggunakan matode diskusi. Guru membagi siswa menjadi beberapa kelompok. Setiap kelompok diberi permasalahan yang berbeda untuk diselesaikan. Selanjutnya masing-masing kelompok diminta untuk mempresentasikan hasil diskusi kelompoknya dan diakhir kegiatan pembelajaran guru mengarahkan siswa untuk menemukan kesimpulan terkait pokok bahasan yang telah didiskusikan

\section{KESIMPULAN}

Berdasarkan hasil penelitian dan pembahasan, maka dapat disimpulkan bahwa interaksi siswa dan guru pada pembelajaran matematika di kelas XII TKJ-1 SMK Negeri 7 Samarinda bervariasi, ada saatnya interaksi yang terjadi berlangsung satu arah, dua arah dan banyak arah. Interaksi satu arah cenderung terjadi pada kegiatan awal pembelajaran yaitu ketika guru mengucapkan salam, menyapa siswa dan terkadang guru memberikan nasihat dan motivasi belajar kepada siswa. Interaksi dua arah terjadi ketika kegiatan Tanya jawab antara guru dengan siswa baik saat apersepsi di awal kegaiatan pembelajaran maupun ketika kegiatan inti pembelajaran yaitu ketika guru dan siswa menbahas materi yang menjadi sub pokok bahasan. Sedangkan interaksi banyak arah terjadi pada saat guru meminta siswa melakukan kegiatan diskusi untuk memecahkan sebuah permasalah dan setelah itu diikuti dengan kegiatan presentasi dari kegiatan diskusi tersebut. Adapun faktor yang mendasari terjadinya interaksi siswa dan guru dalam pembelajaran matematika di kelas XII TKJ-1 SMK Negeri 7 Samarinda Tahun Ajaran 2015/2016 adalah sebagai berikut: a) Upaya maksimalnya guru dalam menggunakan sarana-sarana yang dapat menunjang terwujudnya interaksi dalam proses pembelajaran; b) Minat siswa terhadap mata pelajaran matematika; c)Inteligensi siswa; d) Anggapan mata pelajaran jurusan lebih penting; e) Kondisi kelas yang kurang mendukung untuk jumlah siswa yang ada di kelas; dan f) Pemanfaatan sumber-sumber pelajaran dari pihak siswa.

\section{DAFTAR PUSTAKA}

Kementerian Pendidikan dan Kebudayaan. (2013). Peraturan Menteri Pendidikan dan Kebudayaan Nomor 81 A Tahun 2013: Implementasi Kurikulum. Jakarta.

Permatasari, I., Rudhito, M.A., Sriyanto, H.J. (2011). Interaksi Guru dan Siswa dalam Pembelajaran Matematika Topik Kaidah pencacahan dengan Menggunakan Buku Ajar di Kelas XI IPA SMA Kolese De Brito. Prosiding Semnas Matematika dan Pendidikan, Universitas Negeri Yogyakarta.

Sardiman. (2014). Interaksi dan Motivasi Belajar-Mengajar. Jakarta: Rajawali Pers

Uno, H. (2012). Model Pembelajaran Menciptakan Proses Belajar Mengajar yang Kreatif dan Efektif. Jakarta: Bumi Aksara. 